\title{
Metabolism of the mussel Mytilus galloprovincialis from two origins in the Ría de Arousa (north-west Spain)
}

\author{
Jose M.F. Babarro, María José Fernández-Reiriz* and Uxío Labarta \\ C.S.I.C. Instituto de Investigaciones Marinas, c/Eduardo Cabello, 6, E-36208 Vigo, Spain \\ *E-mail: mjreiriz@iim.csic.es
}

\begin{abstract}
Mussel seed Mytilus galloprovincialis (Bivalvia: Mytilidae) from two origins (rocky shore and collector ropes) was cultivated on a raft in the Ría de Arousa (north-west Spain), from seeding to thinning out, for $226 \mathrm{~d}$ (November 1995-July 1996) and two aspects of metabolism, oxygen consumption rate $\left(\mathrm{VO}_{2}\right)$ and ammonia excretion rate $\left(\mathrm{VNH}_{4}-\mathrm{N}\right)$ were studied in situ.

The model derived from multiple analysis of oxygen consumption accounted for $91.9 \%$ of the variance, based on dry weight of the mussels and the environmental factors quality of food (organic content) and mainly chlorophyll- $a$. Seed origin also showed significant influence. The seasonal pattern of the oxygen consumption can be attributed mainly to the variation of chlorophyll- $a$, which showed a higher range of values in the spring months.

Origin of seed did not show a homogeneous effect on oxygen consumption throughout the cultivation period. Collector rope mussels showed higher oxygen consumption values at the beginning of the cultivation period and after the first $15 \mathrm{~d}$, but the rocky shore mussels showed a higher oxygen consumption between days 22 and 110. Energy-conserving patterns and lower condition index at the onset of the experiment for rocky shore mussels could explain these initial differences.

Multiple analysis on the variation of ammonia excretion rate provided a model that accounted for $72.6 \%$ of the variance based on dry weight of mussels, seed origin and the environmental parameters chlorophyll- $a$ and total particulate matter. The rocky shore mussels showed a significantly higher excretion values for most of the cultivation period, although there was no constant tendency throughout. High excretion values were recorded between January and March, whilst for the rest of the cultivation period values were low.
\end{abstract}

The O:N index was higher in collector rope mussels for most of the cultivation period, which may suggest a more favourable energy metabolism and/or a more appropriate nutritional state for these specimens.

\section{INTRODUCTION}

In studies of physiological energetic, oxygen consumption and nitrogen excretion rates represent the costs and losses of energy associated with metabolism. The physiological responses of bivalve molluscs to changes in the environment are extremely variable (Bayne \& Widdows, 1978; Widdows et al., 1984; Tedengren et al., 1990; Navarro et al., 1991), and the adaptation of each population to the specific characteristics of their habitats have on occasion made it possible to establish effects linked to origin when specimens are subjected or transplanted to new environmental and/or nutritional conditions. These responses have been collectively defined by Mallet et al. (1987) as the 'ecological memory' of the specimens with regard to their original habitat when they are placed in a different environment. To this effect, differences in growth linked to origin (collector rope and rocky shore mussels) have been observed for mussels cultivated on a raft (Pérez Camacho et al., 1995; Babarro et al., 2000a). In the case of physiological parameters for Mytilus edulis and Mytilus galloprovincialis, Okumus \& Stirling (1994), in a natural environment, and Labarta et al. (1997) under laboratory conditions respectively, observed a significant effect of origin on ammonia excretion, but not on oxygen consumption. Widdows et al. (1984) did however find differences in both physiological rates, but at specific times during the annual cycle.

In this study we analyse the physiological rates of oxygen consumption and ammonia excretion in mussels from collector rope and rocky shore origins when both are cultivated on a raft from a length of 20 to $60 \mathrm{~mm}$, and evaluate their behaviour in terms of endogenous and environmental factors.

\section{MATERIALS AND METHODS \\ Harvesting and maintenance of mussels}

In November 1995 seed of Mytilus galloprovincialis Lmk of approximately $20 \mathrm{~mm}$ in length was gathered from the rocky shore and collector ropes on a raft, both in the mid-outer area of the Ría de Arousa (Galicia, north-west Spain). Both groups of mussels were detached from rocks and ropes respectively and subsequently allowed reattaching to cultivation ropes on the raft by using the standard procedure of the mussel culture in Spain (linen net which degraded itself after some days in seawater). Both types of seed, from the same year class, came from spawning period in the previous spring-summer and the 
Table 1. Characteristics of the natural seston (means $\pm S D$ ).

\begin{tabular}{|c|c|c|c|c|c|c|c|c|c|c|}
\hline Date & $\begin{array}{l}\mathrm{TPM} \\
(\mathrm{mg} / \mathrm{l})\end{array}$ & $\begin{array}{l}\mathrm{POM} \\
(\mathrm{mg} / \mathrm{l})\end{array}$ & $\begin{array}{l}\text { PIM } \\
(\mathrm{mg} / \mathrm{l})\end{array}$ & $\begin{array}{c}\mathrm{Vol} \\
\left(\mathrm{mm}^{3} / \mathrm{l}\right)\end{array}$ & $\begin{array}{c}\mathrm{T} \\
\left({ }^{\circ} \mathrm{C}\right)\end{array}$ & $\begin{array}{c}\mathrm{S} \\
(\%)\end{array}$ & $\begin{array}{l}\text { Chl- } a \\
(\mu \mathrm{g} / \mathrm{l})\end{array}$ & $\begin{array}{c}\mathrm{Q}_{\mathrm{t}} \\
(\mathrm{POM} / \mathrm{TPM})\end{array}$ & $\begin{array}{c}\mathrm{Q}_{2} \\
(\mathrm{POM} / \mathrm{Vol})\end{array}$ & Chl- $a /$ POM \\
\hline $27 / 11 / 95$ & $0.68 \pm 0.18$ & $0.37 \pm 0.11$ & 0.30 & $0.57 \pm 0.29$ & $15.7 \pm 0.7$ & $32.8 \pm 1.9$ & $0.75 \pm 0.18$ & 0.55 & 0.65 & 2.02 \\
\hline $05 / 12 / 95$ & $0.49 \pm 0.15$ & $0.29 \pm 0.04$ & 0.20 & $0.39 \pm 0.21$ & $15.4 \pm 1.1$ & $31.3 \pm 4.7$ & $0.36 \pm 0.27$ & 0.59 & 0.75 & 1.25 \\
\hline $13 / 12 / 95$ & $0.83 \pm 0.11$ & $0.31 \pm 0.03$ & 0.52 & $0.52 \pm 0.09$ & $15.6 \pm 0.4$ & $35.2 \pm 0.5$ & $0.48 \pm 0.15$ & 0.38 & 0.60 & 1.52 \\
\hline $20 / 12 / 95$ & $0.74 \pm 0.21$ & $0.37 \pm 0.08$ & 0.36 & $0.45 \pm 0.08$ & $13.7 \pm 0.4$ & $34.8 \pm 0.4$ & $0.61 \pm 0.15$ & 0.51 & 0.82 & 1.63 \\
\hline 03/01/96 & $2.56 \pm 0.68$ & $1.00 \pm 0.27$ & 1.56 & $1.29 \pm 0.09$ & $14.3 \pm 0.3$ & $30.1 \pm 2.9$ & $0.36 \pm 0.36$ & 0.39 & 0.78 & 0.36 \\
\hline $17 / 01 / 96$ & $0.79 \pm 0.06$ & $0.46 \pm 0.02$ & 0.33 & $0.51 \pm 0.08$ & $13.9 \pm 0.6$ & $28.0 \pm 4.8$ & $0.29 \pm 0.28$ & 0.59 & 0.90 & 0.62 \\
\hline $31 / 01 / 96$ & $0.55 \pm 0.07$ & $0.28 \pm 0.03$ & 0.27 & $0.29 \pm 0.05$ & $13.2 \pm 0.3$ & $30.1 \pm 1.4$ & $0.64 \pm 0.27$ & 0.51 & 0.95 & 2.32 \\
\hline $15 / 02 / 96$ & $1.34 \pm 0.20$ & $0.39 \pm 0.06$ & 0.95 & $0.71 \pm 0.06$ & $13.9 \pm 0.6$ & $31.1 \pm 2.2$ & $1.43 \pm 0.35$ & 0.29 & 0.54 & 3.70 \\
\hline $28 / 02 / 96$ & $1.31 \pm 0.11$ & $0.57 \pm 0.08$ & 0.74 & $1.07 \pm 0.14$ & $12.9 \pm 0.4$ & $34.1 \pm 1.4$ & $1.16 \pm 0.18$ & 0.43 & 0.53 & 2.05 \\
\hline $13 / 03 / 96$ & $0.88 \pm 0.22$ & $0.46 \pm 0.10$ & 0.42 & $0.90 \pm 0.29$ & $13.1 \pm 0.1$ & $34.9 \pm 0.4$ & $1.19 \pm 0.37$ & 0.52 & 0.51 & 2.59 \\
\hline $27 / 03 / 96$ & $0.96 \pm 0.17$ & $0.52 \pm 0.08$ & 0.44 & $1.26 \pm 0.26$ & $13.8 \pm 0.2$ & $33.1 \pm 0.4$ & $1.71 \pm 0.28$ & 0.54 & 0.41 & 3.27 \\
\hline $10 / 04 / 96$ & $1.38 \pm 0.12$ & $0.64 \pm 0.04$ & 0.74 & $1.66 \pm 0.15$ & $14.4 \pm 0.5$ & $32.5 \pm 2.7$ & $1.96 \pm 1.60$ & 0.47 & 0.39 & 3.04 \\
\hline $24 / 04 / 96$ & $0.74 \pm 0.09$ & $0.39 \pm 0.02$ & 0.35 & $0.65 \pm 0.15$ & $15.0 \pm 0.6$ & $33.7 \pm 1.7$ & $1.59 \pm 0.35$ & 0.53 & 0.60 & 4.05 \\
\hline 05/06/96 & $0.62 \pm 0.09$ & $0.29 \pm 0.04$ & 0.33 & $0.76 \pm 0.10$ & $15.0 \pm 1.2$ & $35.0 \pm 0.9$ & $1.11 \pm 0.59$ & 0.46 & 0.38 & 3.86 \\
\hline 03/07/96 & $0.72 \pm 0.13$ & $0.43 \pm 0.08$ & 0.29 & $0.64 \pm 0.16$ & $14.3 \pm 0.7$ & $35.6 \pm 0.2$ & $1.03 \pm 0.30$ & 0.60 & 0.67 & 2.38 \\
\hline
\end{tabular}

TPM, total particulate matter; POM, particulate organic matter; PIM, particulate inorganic matter; Vol, total particulate volume; $\mathrm{T}$, temperature; S, salinity; Chl- $a$, chlorophyll- $a$; $\mathrm{Q}_{2}$, organic content (by weight). $\mathrm{Q}_{2}$, organic content (by volume); Chl- $a / \mathrm{POM}$, chlorophyll- $a$ content (by total organic weight).

sampling locations are $2 \mathrm{~km}$ away from each other. Experimental cultivation, which was carried out in a raft usually employed for the culture in Ría de Arousa $\left(500 \mathrm{~m}^{2}\right)$, began in winter with the aim of minimizing any possible advantages accruing to the collector ropes seed as a result of its better adaptation to raft cultivation. The experiment continued until July 1996 (226 d) and covered the first stage of mussel cultivation from seeding to thinning out $(50-60 \mathrm{~mm})$. Sixteen cultivation ropes $(12 \mathrm{~m})$ were used, eight for each type of seed, hung alternately and with a density of $19 \mathrm{~kg}$ of seed per rope $(1.6 \mathrm{~kg} / \mathrm{m}$ of rope or $2600 \mathrm{ind} / \mathrm{m}$ of rope). Sampling was performed by removing mussels from adjacent ropes at an average depth of 2-4 $\mathrm{m}$ for both groups of seed.

The initial length (mean $\pm \mathrm{SD}$ ) of the seed was $22.55 \pm 1.55 \mathrm{~mm}$ for collector ropes and $19.02 \pm 1.93 \mathrm{~mm}$ for the rocky shore mussels. Mean total dry weight (shell plus soft tissues) was $0.36 \pm 0.06$ and $0.27 \pm 0.06 \mathrm{~g}$ /ind for each type of seed, respectively. No significant differences in length and total dry weight were observed between both types of seed at the beginning of the experiment (ANOVA; $P>0.05 ; \mathrm{N}=300)$. The final length (mean $\pm \mathrm{SD}$ ) achieved for both groups of mussels in July 1996 was $55.61 \pm 1.60 \mathrm{~mm}$ for collector ropes and $50.11 \pm 1.96 \mathrm{~mm}$ for the rocky shore mussels. Mean total dry weight (shell plus soft tissues) at the end of the experimental period was $4.74 \pm 0.23$ and $3.08 \pm 0.30 \mathrm{~g} /$ ind for each type of seed, respectively (ANOVA; $P<0.001 ; \mathrm{N}=300$ ).

\section{Measurements}

Natural seston was characterized as total particulate matter (TPM mg/l), particulate organic matter (POM $\mathrm{mg} / \mathrm{l}$ ), particulate inorganic matter (PIM mg/l), particulate volume $(\mathrm{Vol} \mathrm{mm} / \mathrm{l})$ and chlorophyll- $a(\operatorname{chl}-a \mu \mathrm{g} / \mathrm{l})$. Chlorophyll- $a$ values as well as temperature $\left(\mathrm{T}^{\circ} \mathrm{C}\right)$ and salinity ( $\mathrm{S} \mathrm{psu}$ ) values of the water column were provided by the Centro de Control da Calidade do Medio Mariño da Consellería de Pesca, Marisqueo e Acuicultura

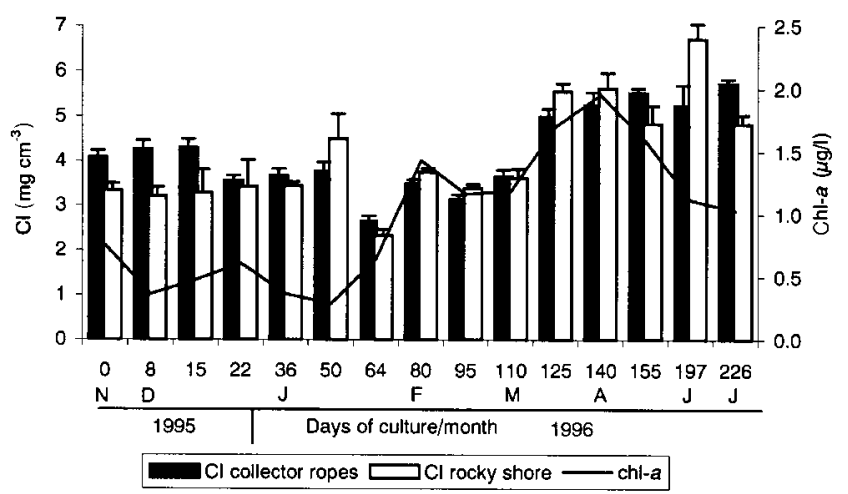

Figure 1. Fluctuation of condition index values $\left(\mathrm{mg} \mathrm{cm}^{-3}\right)$ for rocky shore and collector ropes mussels and chlorophyll- $a$ concentration throughout the cultivation time.

(Xunta de Galicia). Seston quality was expressed as $Q$ $(\mathrm{POM} / \mathrm{TPM}), \mathrm{Q}_{2}(\mathrm{POM} / \mathrm{Vol})$ and the chl- $a / \mathrm{POM}$ index. Seawater samples were filtered onto pre-ashed $\left(450^{\circ} \mathrm{C}\right.$ for $\left.4 \mathrm{~h}\right)$ and weighed GFC filters and rinsed with isotonic ammonium formate $(0.5 \mathrm{M})$. Total dry matter was established as the weight increment determined after drying the filters to constant weight at $110^{\circ} \mathrm{C}$ for $12 \mathrm{~h}$ with an accuracy of $0.001 \mathrm{mg}$. Organic matter corresponded to the weight loss after ignition at $450^{\circ} \mathrm{C}$ for $4 \mathrm{~h}$ in a muffle furnace. Particulate volume per litre of seawater was determined by counting in the range of $2-56 \mu \mathrm{m}$ using a Coulter Counter Multisizer II fitted with a $100-\mu \mathrm{m}$ aperture tube. The variation in these environmental and/or nutritional parameters over the cultivation period is shown in Table 1 and was described in a previous paper (Babarro et al., 2000a).

\section{Metabolic rate $\left(\mathrm{VO}_{2}\right)$}

The metabolic rate was obtained by measuring the oxygen consumption $\left(\mathrm{VO}_{2}\right)$. Mussels were placed in 
Table 2. Values of physiological parameters (mean $\pm S D ; \mathcal{N}=30$ ) of two sources of seed mussel standardized to tissue dry weight ( $D W m g$ ) according to growth of Mytilus galloprovincialis Lmk during the experiment.

\begin{tabular}{|c|c|c|c|c|c|c|}
\hline Date & $\begin{array}{c}\text { Days of } \\
\text { cultivation }\end{array}$ & Source of seed mussel & $\begin{array}{l}\text { DW } \\
\text { mg }\end{array}$ & $\begin{array}{c}\mathrm{VO}_{2} \\
\left(\mathrm{ml} \mathrm{O}_{2} / \mathrm{h}\right)\end{array}$ & $\begin{array}{c}\mathrm{VNH}_{4}-\mathrm{N} \\
\left(\mu \mathrm{g} \mathrm{NH} \mathrm{NH}_{4}-\mathrm{N} / \mathrm{h}\right)\end{array}$ & O:N Index \\
\hline \multirow[t]{2}{*}{$27 / 11 / 95$} & 0 & Collector ropes & 50 & $0.050 \pm 0.007 * * *$ & $1.57 \pm 0.42 * *$ & 39.84 \\
\hline & & Rocky shore & & $0.040 \pm 0.011$ & $2.33 \pm 0.48$ & 21.48 \\
\hline \multirow[t]{2}{*}{$05 / 12 / 95$} & 8 & Collector ropes & 50 & $0.038 \pm 0.006$ & $0.50 \pm 0.19$ & 95.54 \\
\hline & & Rocky shore & & $0.038 \pm 0.005$ & $0.71 \pm 0.27$ & 67.35 \\
\hline \multirow[t]{2}{*}{$13 / 12 / 95$} & 15 & Collector ropes & 50 & $0.036 \pm 0.007 *$ & $0.84 \pm 0.23 *$ & 53.74 \\
\hline & & Rocky shore & & $0.032 \pm 0.006$ & $1.11 \pm 0.23$ & 35.96 \\
\hline \multirow[t]{2}{*}{ 20/12/95 } & 22 & Collector ropes & 50 & $0.039 \pm 0.003 * * *$ & $0.68 \pm 0.19$ & 71.98 \\
\hline & & Rocky shore & & $0.053 \pm 0.004$ & $0.86 \pm 0.27$ & 76.83 \\
\hline \multirow[t]{2}{*}{$03 / 01 / 96$} & 36 & Collector ropes & 50 & $0.021 \pm 0.009$ & $0.37 \pm 0.17 * *$ & 70.35 \\
\hline & & Rocky shore & & $0.015 \pm 0.003$ & $0.81 \pm 0.42$ & 23.28 \\
\hline \multirow[t]{2}{*}{$17 / 01 / 96$} & 50 & Collector ropes & 50 & $0.027 \pm 0.004 * * *$ & $0.71 \pm 0.25 * *$ & 47.52 \\
\hline & & Rocky shore & & $0.042 \pm 0.003$ & $1.17 \pm 0.20$ & 44.85 \\
\hline \multirow[t]{2}{*}{$31 / 01 / 96$} & 64 & Collector ropes & 70 & $0.061 \pm 0.004 * * *$ & $2.02 \pm 0.79$ & 37.92 \\
\hline & & Rocky shore & & $0.066 \pm 0.005$ & $1.64 \pm 0.76$ & 50.41 \\
\hline \multirow[t]{2}{*}{$15 / 02 / 96$} & 80 & Collector ropes & 100 & $0.113 \pm 0.006 * * *$ & 2.19 & 64.47 \\
\hline & & Rocky shore & & $0.137 \pm 0.008$ & 2.99 & 57.25 \\
\hline \multirow[t]{2}{*}{$28 / 02 / 96$} & 95 & Collector ropes & 100 & $0.122 \pm 0.013 * *$ & $2.05 \pm 1.35$ & 74.51 \\
\hline & & Rocky shore & & $0.133 \pm 0.009$ & $2.87 \pm 1.73$ & 57.86 \\
\hline \multirow[t]{2}{*}{$13 / 03 / 96$} & 110 & Collector ropes & 200 & $0.184 \pm 0.019 * *$ & $2.21 \pm 0.55$ & 104.03 \\
\hline & & Rocky shore & & $0.200 \pm 0.018$ & $2.56 \pm 0.91$ & 97.66 \\
\hline \multirow[t]{2}{*}{$27 / 03 / 96$} & 125 & Collector ropes & 300 & $0.240 \pm 0.026$ & $2.05 \pm 0.46^{* *}$ & 146.28 \\
\hline & & Rocky shore & & $0.244 \pm 0.028$ & $2.92 \pm 0.81$ & 104.59 \\
\hline \multirow[t]{2}{*}{$10 / 04 / 96$} & 140 & Collector ropes & 400 & $0.361 \pm 0.086$ & 3.13 & 144.11 \\
\hline & & Rocky shore & & $0.335 \pm 0.071$ & 4.10 & 102.09 \\
\hline \multirow[t]{2}{*}{$24 / 04 / 96$} & 155 & Collector ropes & 600 & $0.488 \pm 0.104$ & 7.00 & 87.11 \\
\hline & & Rocky shore & & $0.409 \pm 0.102$ & 8.30 & 61.57 \\
\hline \multirow[t]{2}{*}{ 05/06/96 } & 197 & Collector ropes & 1000 & $0.701 \pm 0.139$ & 8.10 & 108.13 \\
\hline & & Rocky shore & & $0.658 \pm 0.176$ & 9.24 & 88.97 \\
\hline \multirow[t]{2}{*}{$03 / 07 / 96$} & 226 & Collector ropes & 1000 & $0.585 \pm 0.088$ & $6.25 \pm 1.88$ & 116.90 \\
\hline & & Rocky shore & & $0.538 \pm 0.075$ & $7.32 \pm 1.94$ & 91.81 \\
\hline
\end{tabular}

$\mathrm{VO}_{2}$, oxygen consumption rate; $\mathrm{VNH}_{4}-\mathrm{N}$, ammonia excretion rate. $(*, P<0.05 ; * *, P<0.01 ; * * *, P<0.001)$.

closed $780 \mathrm{ml}$ cylindrical chambers (height $85 \mathrm{~mm}$, diameter $115 \mathrm{~mm}$ ) sealed with oxygen probes $\left(\right.$ YSI $^{\circledR}$ 5730). The oxygen concentration was recorded at regular intervals with oxygen meters $\left(\mathrm{YSI}^{\circledR}{ }^{\circledR}\right.$ 58) connected to the probes for approximately $60 \mathrm{~min}$, until the oxygen concentration fell below $30 \%$ of the initial value. One parallel control chamber without animals was always used to correct for bacterial respiration, electrode drift, etc. Metabolic rate was then calculated:

$\mathrm{VO}_{2}=60\left[\mathrm{Ct}_{0}-\mathrm{Ct}_{1}\right]\left[\mathrm{V} /\left(\mathrm{t}_{1}-\mathrm{t}_{0}\right)\right]$

where $\mathrm{Ct}_{0}-\mathrm{Ct}_{1}$ are the concentration of oxygen in the water $\left(\mathrm{mg} \mathrm{O}_{2} / \mathrm{l}\right)$ at start and finish times ( $\left.\mathrm{min}\right)$ respectively; $\mathrm{V}$ is the volume of the chamber; $\mathrm{t}_{1}-\mathrm{t}_{0}$ represent start and finish times ( $\mathrm{min}$ ) of the measured period, respectively.

\section{Ammonia excretion rate $\left(\mathrm{VNH}_{4}-\mathcal{N}\right)$}

Rate of ammonia excretion was determined by placing mussels in closed chambers filled with $250 \mathrm{ml}$ of air-saturated water previously filtered through $0.2 \mu \mathrm{m}$ Millipore membranes. After $150 \mathrm{~min}, 10 \mathrm{ml}$ samples of the water were extracted from each experimental chamber to be analysed following Solorzano's method (1969): $\mu \mathrm{gNH}_{4}-\mathrm{N} / \mathrm{h}=[($ test $-\mu \mathrm{M}$ control $)$

$$
(14 /(1000 / \mathrm{V}))(1 / \mathrm{t})]
$$

where $\mathrm{V}$ is the volume of the experimental container $(250 \mathrm{ml})$ and $\mathrm{t}$ is the time of incubation $(2.5 \mathrm{~h})$.

The number of specimens taken into consideration for the physiological measurements varied according to their size (i.e. with the length of cultivation period). At the beginning, eight specimens of $50 \mathrm{mg}$ of tissue dry weight class were placed in each chamber in a set of ten, and this number was also employed for 70 and $100 \mathrm{mg}$ of tissue dry weight classes. From $200 \mathrm{mg}$ of tissue dry weight class onwards the number of animals used progressively decreased and at the end of the experiment there was only one specimen of $1000 \mathrm{mg}$ of tissue dry weight class in each chamber. Physiological measurements were taken weekly from November to December, fortnightly from January to May, and monthly in June and July.

The ratio of oxygen consumed to nitrogen excreted $(\mathrm{O}: \mathrm{N}$ index $)$ was computed by atomic equivalents according to Widdows (1985).

Condition index of the animals was calculated as the individual dry weight per volume. As an index of (shell) volume the length to the third power was used. Variation of this condition index throughout the experimental time 
in relation to chlorophyll- $a$ concentration is shown in the Figure 1.

\section{Size standardization}

To preclude variability in physiological rates caused by size differences, these rates were corrected to a standardsized individual according to growth of the animals. Once physiological measurements were completed, shell length of each individual was recorded to the nearest $0.1 \mathrm{~mm}$ with vernier callipers and the soft tissues excised from the shell, dried at $110^{\circ} \mathrm{C}$ for $12 \mathrm{~h}$ and weighed with an accuracy of $0.01 \mathrm{~g}$. Oxygen consumption and ammonia excretion rates were obtained according to the formula:

$\mathrm{Y}_{\mathrm{s}}=\mathrm{Y}_{\mathrm{e}}\left(\mathrm{DW}_{\mathrm{st}} / \mathrm{DW}_{\mathrm{e}}\right)^{\mathrm{b}}$

where $\mathrm{Y}_{\mathrm{s}}$ and $\mathrm{Y}_{\mathrm{e}}$ are the corrected and non-corrected physiological rates respectively, $\mathrm{DW}_{\mathrm{st}}$ is the range $50-1000 \mathrm{mg}$ of tissue dry weight, $\mathrm{DW}_{\mathrm{e}}$ is the experimental weight of the mussels (DW in $\mathrm{mg}$ ) and $\mathrm{b}$ is the power value that scales physiological rate to body weight: $b=0.75$ (Bayne $\&$ Newell, 1983) and $b=0.72$ (Hawkins et al., 1985) for the oxygen consumption and ammonia excretion rates respectively. In order to show fluctuation of the physiological rates vs time of culture for a standard size class, $1 \mathrm{~g}$ of tissue dry weight was chosen for both physiological rates.

\section{Data analysis}

Standard analysis of variance (ANOVA) was used to compare means for both physiological rates $\left(\mathrm{VO}_{2}\right.$ and $\left.\mathrm{VNH}_{4}-\mathrm{N}\right)$. Kruskal-Wallis and Friedman non-parametric tests were employed when homogeneity was not obtained (Bartlett's test) after data transformation.

Multiple stepwise regression analysis was used to determine the effect of a variety of factors, both endogenous and environmental, on the variation of oxygen consumption and ammonia excretion rates. The seed origin factor was added to this analysis with values of 0 and 1 for collector rope and rocky shore mussels respectively. Both physiological rate values were transformed by $\log _{10}(x+1)$ to stabilize variances.

All the analyses were carried out in accordance with the statistical methods described by Zar (1984).

\section{RESULTS}

Oxygen consumption $\left(\mathrm{VO}_{2}\right)$

Oxygen consumption values for both groups of mussels (collector rope and rocky shore) throughout the experimental cultivation period are shown in Table 2 .

Oxygen consumption rate was $25 \%$ higher in collector rope mussels than those of rocky shore origin at the beginning of the culture period $(P<0.001$; Table 2$)$. After $8 \mathrm{~d}, \mathrm{VO}_{2}$ was lower for both types of seed, although this decrease was greater for collector rope mussels, which meant no difference between them $(P>0.05)$. The initial differences observed between both types of seed reappeared after $15 \mathrm{~d}$ of cultivation on the raft $(P<0.05$; Table 2$)$. However, between days 22 and 110 of the culture period the differences in $\mathrm{VO}_{2}$ were inverted, and this rate was
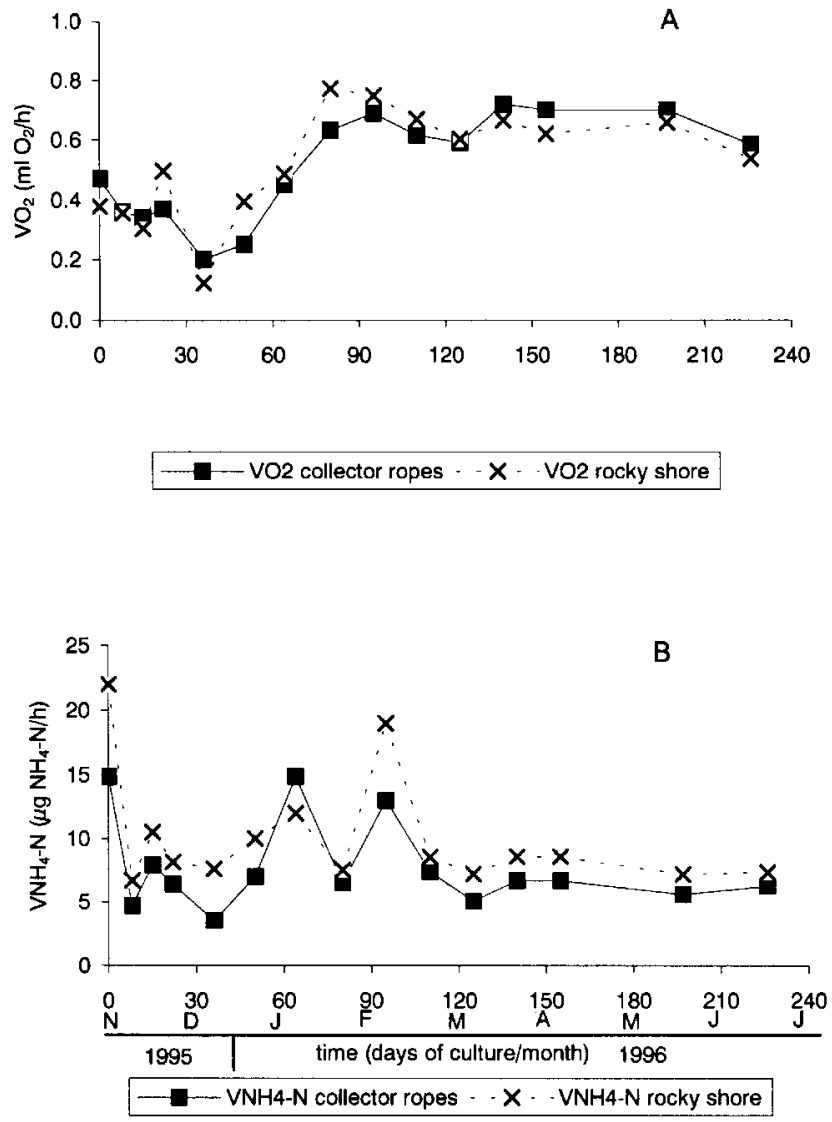

Figure 2. Variation of oxygen consumption $\left(\mathrm{VO}_{2}\right)$ and ammonia excretion $\left(\mathrm{VNH}_{4}-\mathrm{N}\right)$ rates throughout the cultivation time. Both physiological rates have been standardized to $1 \mathrm{~g}$ of tissue dry weight.

significantly higher in the rocky shore mussels when compared to the collector rope specimens (Table 2). After day 110 of cultivation on the raft, $\mathrm{VO}_{2}$ values were similar for both groups of mussels $(P>0.05)$.

\section{Oxygen consumption vs cultivation time}

Variation of oxygen consumption for $1 \mathrm{~g}$ of tissue dry weight class over the experimental period is shown in Figure 2A. During the first $15 \mathrm{~d}, \mathrm{VO}_{2}$ showed an acclimation response to the experimental cultivation conditions, as has been described above. After this initial period, oxygen consumption fluctuation clearly corresponded to a seasonal model: low values during the winter months and a rise of this physiological rate in the spring and summer months (Figure 2A). There was a strong variation in $\mathrm{VO}_{2}$ during wintertime (a range of $0.123-0.497 \mathrm{ml} \mathrm{O}_{2} / \mathrm{h}$ for both types of mussels). On the other hand, there was greater uniformity in the spring-summer period with values ranging from $0.538-0.772 \mathrm{ml} \mathrm{O}_{2} / \mathrm{h}$ for both groups of mussels.

\section{Oxygen consumption vs dry weight and environmental parameters}

The effect of mussel growth (weight) and the variation of environmental factors on oxygen consumption, as well as the seed origin factor, was studied by means of a multiple regression analysis (Table 3). The model thus 
Table 3. Stepwise multiple regression of log physiological rates of Mytilus galloprovincialis ( $\mathrm{VO}_{2}$, oxygen consumption rate and $\mathrm{VNH}_{4}-\mathcal{N}$, excretion rate) with logarithm of tissue dry weight $(\log D W)$, quality of seston $\left(Q_{1}=P O M / T P M\right)$, temperature $\left(T^{\circ} \mathrm{C}\right)$, chlorophyll-a $(\mu \mathrm{g} / \mathrm{l})$, total particulate matter (TPM mg/l) and origin of seed.

\begin{tabular}{lrrrr}
\hline \multirow{2}{*}{ Parameter } & \multicolumn{2}{c}{$\mathrm{VO}_{2}$} & & \\
& Coefficient & $\mathrm{SE}$ & $F$-ratio & $P$ \\
\hline Constant & -2.505 & & & \\
Log DW & 0.647 & 0.014 & 2081.016 & $<0.001$ \\
$\mathrm{Q}_{1}$ & 0.191 & 0.065 & 8.706 & $<0.01$ \\
$\mathrm{~T}$ & -0.013 & 0.006 & 5.123 & $\simeq 0.05$ \\
Chl- $a$ & 0.255 & 0.015 & 278.525 & $<0.001$ \\
Origin & 0.069 & 0.010 & 46.018 & $<0.001$ \\
\hline
\end{tabular}

$r^{2}=0.919 ; \mathrm{N}=720 ; F_{5,174}=1620.962 ; P<0.001$.

\begin{tabular}{lrrrc}
\hline & \multicolumn{2}{c}{$\mathrm{VNH}_{4}-\mathrm{N}$} & & \\
Parameter & Coefficient & SE & $F$-ratio & $P$ \\
\hline Constant & -1.098 & & & \\
Log DW & 0.567 & 0.047 & 147.610 & $<0.001$ \\
Chl- $a$ & 0.191 & 0.049 & 15.233 & $<0.001$ \\
Origin & 0.108 & 0.031 & 11.903 & $<0.01$ \\
TPM & -0.110 & 0.029 & 13.951 & $<0.001$
\end{tabular}

$\mathrm{r}^{2}=0.726 ; \mathrm{N}=180 ; F_{4,175}=139.610 ; P<0.001$.

derived accounted for $91.9 \%$ of the variance, which in turn was mostly explained by the logarithm of the weight $(P<0.001)$. The origin factor also showed a highly significant effect whereas temperature, quality of seston $\left(Q_{1}=\right.$ POM $\left./ \mathrm{TPM}\right)$ and in particular chlorophyll- $a$ were the environmental parameters that presented significant influence on the oxygen consumption rate as well (see Table 3).

\section{Oxygen consumption vs chlorophyll-a concentration}

A significant positive linear relationship was established between oxygen consumption rate and chlorophyll$a$ concentration for the whole experimental time (Figure 3). There was no differences between equations of both groups of mussels (collector ropes and rocky shore), therefore it can be shown as a common linear equation (Figure 3):

$\mathrm{VO}_{2}=0.279 \pm 0.035 \quad$ Chl $-a+0.243 ; \quad \mathrm{N}=30 ; \quad r^{2}=0.694 ;$ $P<0.001$

\section{Ammonia excretion $\left(\mathrm{VNH}_{4}-\mathcal{N}\right)$}

Ammonia excretion values of mussels from both origins during the experimental culture period are shown in Table 2.

At the beginning of the experiment, $\mathrm{VNH}_{4}-\mathrm{N}$ was $48 \%$ higher for rocky shore mussels than those from collector ropes $(P<0.01$; Table 2$)$, and no significant differences were observed after $8 \mathrm{~d}$ of cultivation

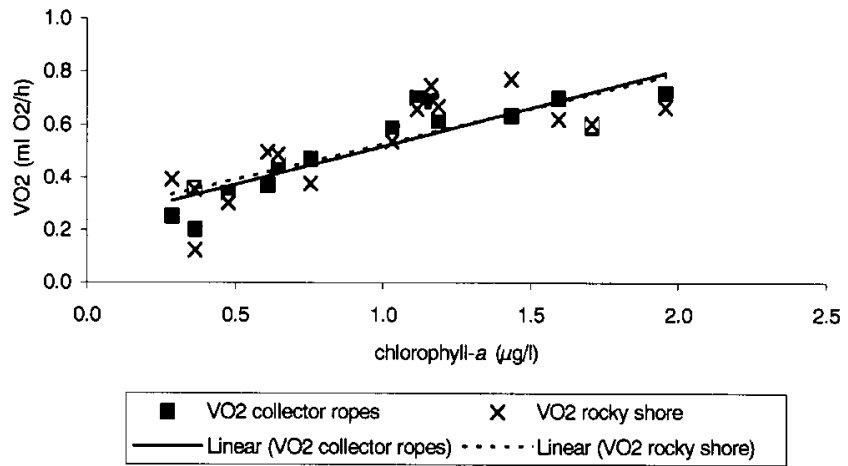

Figure 3. Relationship between oxygen consumption rate and chlorophyll- $a$ concentration throughout the cultivation time for both groups of mussels. The common linear equation corresponding to both groups of mussels together is shown in the text.

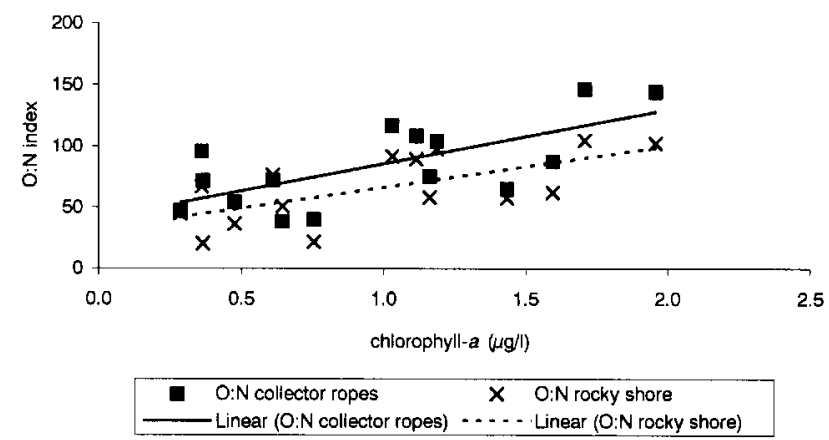

Figure 4. Relationship between $\mathrm{O}: \mathrm{N}$ index and chlorophyll- $a$ concentration during the experimental time for rocky shore and collector ropes mussels. The equations corresponding to the figure are shown in the text.

$(P>0.05)$. After $15 \mathrm{~d}, \mathrm{VNH}_{4}-\mathrm{N}$ continued to be higher in the rocky shore specimens $(P<0.05)$, and this difference persisted over most of the cultivation period, although significant differences could only be observed at certain times (Table 2).

\section{Ammonia excretion vs cultivation time}

Variation of ammonia excretion for $1 \mathrm{~g}$ of tissue dry weight class over the experimental period is shown in Figure 2B. As was the case for oxygen consumption, ammonia excretion decreased between the beginning of the experimental period and day 36. Excretion values increased during January and February, but unlike $\mathrm{VO}_{2}$, dropped again during the spring and summer months, returning to values close to those observed during winter.

\section{Ammonia excretion vs dry weight and environmental parameters}

The effect of mussel growth (weight), their origin, and environmental factors on the ammonia excretion variation was studied by means of a multiple regression analysis (Table 3). The model accounted for $72.6 \%$ of the variation in $\mathrm{VNH}_{4}-\mathrm{N}$, which in turn mostly corresponded to the logarithm of the weight $(P<0.001)$. As was the case for $\mathrm{VO}_{2}$, origin factor showed significant influence whereas environmental parameter importance was 
represented by the effect of chlorophyll- $a$ concentration and total particulate matter.

\section{$O: \mathcal{N}$ index}

The ratio between the oxygen consumption and the ammonia excretion rates, $\mathrm{O}: \mathrm{N}$ index calculated according to their atomic equivalents, indicates the proportion of protein in relation to lipids or carbohydrates that is catabolised for the energy requirements of the metabolism. Thus, a high rate of catabolism of proteins as compared to lipids or carbohydrates is expressed by a low O:N ratio.

The highest O:N index values corresponded to the collector rope mussels for most of the experimental period (Table 2), which may indicate that mussels with this origin had a more favourable energy metabolism.

The O:N index values increased in both types of mussel throughout the experimental period, coinciding with a greater availability of food in the spring and summer months, and one of the effects due to this factor is a higher accumulation of reserve tissues in the mussels. When the $\mathrm{O}: \mathrm{N}$ index is plotted against a factor of food quality like chlorophyll- $a$ concentration, good concordance was achieved throughout the experiment (Figure 4). The corresponding functions for these relationships are:

Collector ropes: $\mathrm{O}: \mathrm{N}=40.71+44.42 \pm 13.23$ Chl- $a ; \mathrm{N}=15$ $r^{2}=0.464 P<0.01$

Rocky shore: $\mathrm{O}: \mathrm{N}=31.70+34.14 \pm 11.04$ Chl- $a ; \mathrm{N}=15$ $r^{2}=0.424 P<0.01$

The covariance analysis performed for the linear equations showed no significant differences between the slopes of both groups $(\mathrm{t}=0.213$; $\mathrm{df}=26 ; P>0.05$; common slope: 39.281). However, the intercept obtained for collector rope mussels was significantly higher than that for the rocky shore specimens $(\mathrm{t}=2.181 ; \mathrm{df}=27 ; P<0.05)$, which means higher $\mathrm{O}: \mathrm{N}$ values for the former group when chlorophyll- $a$ is low, as was the case in wintertime at the onset of the experiment.

\section{DISCUSSION}

Oxygen consumption

The oxygen consumption rate showed a clearly seasonal pattern, with low values being recorded in winter and maximums during spring and early summer. A similar seasonal pattern to that of the present study has been observed on many previous occasions (Bayne \& Widdows, 1978; Widdows, 1978; Navarro \& Thompson, 1996; Smaal et al., 1997). These fluctuations have been related to such factors as temperature, the availability of food, and above all, reproductive condition.

Multiple regression analysis provided a model that accounted for $91.9 \%$ of the variation in oxygen consumption based on weight, origin of seed and environmental factors quality of food, temperature and chlorophyll- $a$. The important role of multifactorial analyses in order to explained physiological variations should be noted; such changes are difficult to explain unless they are associated with specific major factors such as temperature and gametogenic activity (Iglesias \& Navarro, 1991).

In this study, temperature fluctuated in a very narrow range $\left(2.7^{\circ} \mathrm{C}\right.$ between maximum and minimum values), though oxygen consumption rate showed a clear seasonal variation. The significant effect of temperature in the multiple model can be considered residual (Table 3). However, the importance of quality of food $\left(Q_{1}=\mathrm{POM} /\right.$ TPM) and greatly chlorophyll- $a$ (Figure 3 ) on $\mathrm{VO}_{2}$ variation was quite clear. High respiration values throughout spring and early summer can be related to an increase of food quality, which in turn should be interpreted according to the findings of Navarro \& Thompson (1996). These authors reported that low values of food quality (corresponding to a higher proportion of inorganic matter in the total particulate matter) lead to a lessening of metabolic costs, either as a result of a drop in digestive activity and growth when food quality is low (Bayne \& Widdows, 1978; Bayne et al., 1989), or due to the mechanical response of valve closure when there is a high concentration of particles in the water column.

The influence of gametogenesis processes on the oxygen consumption has been widely reported (see Bayne \& Widdows, 1978; Widdows, 1978; Smaal et al., 1997 for some examples). In this survey we observed that mussels from both origins became reproductively active in February-March 1996 when they reached 30-40 mm size class (100-200 mg of dry weight of tissue). In terms of chlorophyll- $a$, the first peak in February (Figure 1) coincided with a high increase of oxygen consumption rate after wintertime. With our experimental design, it is difficult to distinguish between both factors (reproductive stage and chlorophyll- $a$ ) on their importance because reproductive condition was roughly assessed by sight observations.

The inversion of oxygen consumption differences between both groups of seed from day 22 up to day 110 of culture with higher values for rocky shore mussels, relative to first 15 days, may be interpreted according to the increase of clearance and ingestion rates for this type of seed (Babarro et al., in press, b), which would lead to a higher metabolic expenditure. Shick et al. (1988) observed that animals that inhabit rocky shore environments exhibit a characteristic compensatory trait related to energy conservation, given that the environment of these specimens is characterized by desiccation, osmotic stress and temperature changes that would all affect the oxygen consumption rate. Additionally condition index values for the rocky shore mussels were clearly lower for the first two weeks on the raft (Figure 1) which could partly account for these initial differences in $\mathrm{VO}_{2}$ between both groups of mussels.

Other factors that might have showed a significant influence on initial differences like detachment-reattachment of seed mussel from the experimental cultivation ropes, can be considered negligible with our experimental design. Although we did not quantify this energetic demand to re-establish byssal attachment, it is possible to consider that this factor affected both groups of animals in a similar magnitude by removing both seed from their original habitats (collector ropes and rocky shore) and allowing them to re-attach again by standard technique used by the mussel farmers (see Material and Methods). 


\section{Ammonia excretion}

The high initial values of ammonia excretion for both types of seed should be attributed to a state of unsettlement that might cause an initial increase in protein catabolism that quickly fell again after $8 \mathrm{~d}$. A more sustained increase in $\mathrm{VNH}_{4}-\mathrm{N}$ was observed between January and March, which indicates a similar trend to that established by Bayne \& Widdows (1978) for Mytilus edulis between the winter and spring periods.

Importance has traditionally been attached to the effect that factors such as temperature and energy reserves cycle have on the variation of $\mathrm{VNH}_{4}-\mathrm{N}$, since they are closely linked to and have a direct bearing on the reproductive cycle (Bayne \& Scullard, 1977; Bayne \& Widdows, 1978; Bayne \& Newell, 1983; Smaal et al., 1997). The relationship reproductive cycle vs ammonia excretion involves an increase in the protein metabolism, and therefore, in excretion when the gonads reach maturity. Additionally, when glucose reserves are scarce, which can occur in wintertime, an additional energy contribution from protein catabolism may well be needed in the January-March period when the energy produced by the metabolism of glucose could prove to be insufficient, since it could be mainly absorbed by gametogenesis (see above, oxygen consumption). This proposed explanation for the increase in the excretion rate (shortage of glucose reserves and the use of protein metabolism) is in agreement with the findings of other studies under conditions of food scarcity or nutritional stress (Gabbott \& Bayne, 1973; Bayne \& Widdows, 1978).

The significant effect of the seed origin in the present study is in agreement with results obtained under laboratory conditions for collector rope and rocky shore mussels (Labarta et al., 1997). In the present study the rocky shore mussels also showed higher ammonia excretion values than those for collector rope specimens, and the extension of these differences over the most part of the experimental time may indicate, as has been suggested by Okumus (1993), a slow process of adaptation for this particular physiological rate, which would include osmotic adjustments in which the pool of free amino acids plays an important role. This may be especially important in littoral habitats, with periods of exposure to the air, and for this reason the disturbances caused by transplanting these specimens to the cultivation conditions that exist when suspended from a raft may well last for some considerable time.

\section{$O: \mathcal{N}$ index}

As an integration of oxygen consumption and ammonia excretion rate fluctuations, the $\mathrm{O}: \mathrm{N}$ index showed a seasonal variation, with low values in winter and a gradual increase in spring. Low $\mathrm{O}: \mathrm{N}$ index values have been associated with situations of limited availability of food (Kreeger, 1993) and this could be associated in our study with wintertime. In spring and early summer, a quite considerable increase in chlorophyll- $a$ content implied higher O:N index values (Figure 4).

Widdows (1985) pointed out that O:N values below 30, which correspond to those of rocky shore origin at the beginning of the experimental period, lie on the threshold of stress. The reason for this is that whilst the oxygen consumption rate has been described as diet-dependent and drops dramatically within inanition situations (Bayne et al., 1989), the excretion rate increases when food is scarce, as a result of the increase in protein catabolism (Gabbott \& Bayne, 1973; Bayne \& Scullard, 1977). Bayne \& Scullard (1977) have suggested that the use of the $\mathrm{O}: \mathrm{N}$ index as a stress indicator is only appropriate if the seasonal cycles of gametogenesis/energy reserves are taken into account, since although feeding conditions may be excellent, the $\mathrm{O}: \mathrm{N}$ index can decrease during the spawning period (Widdows, 1985).

In this study, collector rope mussels showed higher values than the rocky shore specimens for this index, which can be interpreted as an indicator of the better nutritional condition of the former specimens. Kreeger (1993) described low O:N index values in states of nutritional deprivation, which are characteristic of areas where food is scarce, as is the case of the original habitat for rocky shore mussels. The availability of food is the major differential factor with regard to the characteristics of the original habitats in the present study (collector rope and rocky shore), and the differences observed in the $\mathrm{O}: \mathrm{N}$ index at the beginning of the experimental period $(42-85 \%$ higher for the collector rope mussels for the first two weeks), together with the wide variation in these differences throughout the experiment, which are nevertheless almost always in favour of the collector rope mussels, may be accounted for by the persistence of ammonia excretion differences in spite of a long period of acclimatization. The present experiment began in winter, a period in which the possible differences in protein metabolism between the two groups under study are thought to be at their lowest. However, with the arrival of a period with greater availability of food, the differences in this metabolism may be enhanced, especially once the carbohydrate reserves have been deviated to reproductive processes.

The differences in the $\mathrm{O}: \mathrm{N}$ index throughout a large part of the experimental period related to ammonia excretion behaviour are indicative of slow process of adaptation for this physiological rate when specimens are subjected to new environmental and/or nutritional conditions, as occurs when rocky shore mussels are transferred to a raft for cultivation.

We are grateful to Lourdes Nieto, Beatriz González and Sonia Villar for technical assistance. We also thank Juan Maneiro from Centro de Control da Calidade do Medio Mariño da Consellería de Pesca, Marisqueo e Acuicultura (Xunta de Galicia) for environmental parameters determination. The authors are also indebted to the crew of 'José María Navaz' from the Instituto Español de Oceanografía. This work was supported by Project CICYT MAR97-0592. J.M.F.B. was funded by a grant from Excma., Diputación de Pontevedra.

\section{REFERENGES}

Babarro, J.M.F., Fernández-Reiriz, M.J. \& Labarta, U., 2000a. Growth of seed mussel (Mytilus galloprovincialis Lmk): effects of environmental parameters and seed origin. Journal of Shellfish Research, 19, in press.

Babarro, J.M.F., Fernández-Reiriz, M.J. \& Labarta, U., 2000b. Feeding behaviour of seed mussel Mytilus galloprovincialis: environmental parameters and seed origin. Fournal of Shellfish Research, 19, in press. 
Bayne, B.L., Hawkins, A.J.S., Navarro, E. \& Iglesias, J.I.P., 1989. Effects of seston concentration on feeding, digestion and growth in the mussel Mytilus edulis. Marine Ecology Progress Series, 55, 47-54.

Bayne, B.L. \& Newell, R.C., 1983. Physiological energetics of marine mollusc. In The Mollusca. Vol. 4. Physiology, Part 1 (ed. K.M. Wilbur), pp. 407-515. New York: Academic Press.

Bayne, B.L. \& Scullard, C., 1977. Rates of nitrogen excretion by species of Mytilus (Bivalvia: Mollusca). Fournal of the Marine Biological Association of the United Kingdom, 57, 355-369.

Bayne, B.L. \& Widdows, J., 1978. The physiological ecology of two populations of Mytilus edulis L. Oecologia, 37, 137-162.

Gabbott, P.A. \& Bayne, B.L., 1973. Biochemical effects of temperature and nutritive stress on Mytilus edulis L. Fournal of the Marine Biological Association of the United Kingdom, 53, 269286.

Hawkins, A.J.S., Salked, P.N., Bayne, B.L., Gnaiger, E. \& Lowe, D.M., 1985. Feeding and resource allocation in the mussel Mytilus edulis: evidence for time-averaged optimization. Marine Ecology Progress Series, 20, 273-287.

Iglesias, J.I.P. \& Navarro, E., 1991. Energetics of growth and reproduction in cockles (Cerastoderma edule): seasonal and agedependent variations. Marine Biology, 111, 359-368.

Kreeger, D.A., 1993. Seasonal patterns in utilization of dietary protein by the mussel Mytilus trossulus. Marine Ecology Progress Series, 95, 215-232.

Labarta, U., Fernández-Reiriz, M.J. \& Babarro, J.M.F., 1997. Differences in physiological energetics between intertidal and raft cultivated mussels Mytilus galloprovincialis. Marine Ecology Progress Series, 152, 167-173.

Mallet, A.L., Carver, C.E.A., Goffen, S.S. \& Freeman, K.R., 1987. Winter growth of the blue mussel Mytilus edulis L.: importance of stock and site. Fournal of Experimental Marine Biology and Ecology, 108, 217-228.

Navarro, E., Iglesias, J.I.P., Pérez Camacho, A., Labarta, U. \& Beiras, R., 1991. The physiological energetics of mussels (Mytilus galloprovincialis Lmk.) from different cultivation rafts in the Ría de Arosa (Galicia, N.W. Spain). Aquaculture, 94, 197-212.

Navarro, J.M. \& Thompson, R.J., 1996. Physiological energetics of the horse mussel Modiolus modiolus in a cold ocean environment. Marine Ecology Progress Series, 138, 135-148.
Okumus, I., 1993. Evaluation of suspended mussel (Mytilus edulis L.) culture and integrated experimental mariculture with salmon in Scottish sea lochs. PhD thesis, University of Stirling, Scotland.

Okumus, I. \& Stirling, H.P., 1994. Physiological energetics of cultivated mussel (Mytilus edulis) populations in two Scottish west coast sea lochs. Marine Biology, 119, 125-131.

Pérez Camacho, A., Labarta, U. \& Beiras, R., 1995. Growth of mussels (Mytilus edulis galloprovincialis) on cultivation rafts: influence of seed source, cultivation site and phytoplankton availability. Aquaculture, 138, 349-362.

Shick, J.M., Widdows, J. \& Gnaiger, E., 1988. Calorimetric studies of behavior, metabolism and energetics of sessile intertidal animals. American Zoologist, 28, 161-181.

Smaal, A.C., Vonck, A.P.M.A. \& Bakker, M., 1997. Seasonal variation in physiological energetics of Mytilus edulis and Cerastoderma edule of different size classes. Fournal of the Marine Biological Association of the United Kingdom, 77, 817-838.

Solorzano, L., 1969. Determination of ammonia in natural waters by the phenolhypochlorite method. Limnology and Oceanography, 14, 799-801.

Tedengren, M., André, C., Johannesson, K. \& Kautsky, N., 1990. Genotypic and phenotypic differences between Baltic and North Sea populations of Mytilus edulis evaluated through reciprocal transplantations. III. Physiology. Marine Ecology Progress Series, 59, 221-227.

Widdows, J., 1978. Combined effects of body size, food concentration and season on the physiology of Mytilus edulis. Fournal of the Marine Biological Association of the United Kingdom, 58, 109124.

Widdows, J., 1985. Physiological measurements. In The effects of stress and pollution on marine animals (ed. B.L. Bayne et al.), pp. 3-45. New York: Praeger.

Widdows, J., Donkin, P., Salked, P.N., Cleary, J.J., Lowe, D.M., Evans, S.V. \& Thompson, P.E., 1984. Relative importance of environmental factors in determining physiological differences between two populations of mussels (Mytilus edulis). Marine Ecology Progress Series, 17, 33-47.

Zar, J.H., 1984. Biostatistical analysis. Englewood Cliffs, NJ: Prentice-Hall.

Submitted 8 October 1999. Accepted 15 May 2000. 